\title{
PENGARUH KARAKTERISTIK PSIKOGRAFIS KONSUMEN, SIKAP TERHADAP VIDEO TUTORIAL MAKE-UP, DAN CITRA MERK PADA MINAT BELI
}

\author{
Dela Fransiska A. \\ Ike Janita Dewi ${ }^{2}$ \\ Fakultas Ekonomi, Universitas Sanata Dharma \\ (ikejanitadewi@yahoo.com) \\ DOI: doi.org/10.24071/exero.2018.010102
}

\begin{abstract}
This research aims to examine the influence of consumer psychographic characteristics (purchase experience, consumer innovativeness, vanity seeking, and variaty seeking behavior) on attitudes towards makeup tutorial videos, the influence of attitude towards on makeup tutorial videos on brand image and the influence of brand image on purchase interest. Data was collected through a survey on 300 female respondents in Yogyakarta Special Region and Central Java, aged 15-45 years old. Data were analyzed using linear regression analysis. The results showed that purchase experience, vanity seeking behavior, and variety seeking behavior positively effect attitudes towards makeup tutorials video, while consumer innovativenes does not affect attitude towards makeup tutorial video. Attitudes towards makeup tutorials video positively effect brand image and brand image positively effect purchase intention.
\end{abstract}

Keywords:purchase experience; consumer innovativeness; vanity seeking; variety seeking; attitude towards make-up tutorial videos; brand image; purchase intention

\section{PENDAHULUAN}

Revolusi internet memberikan peluang dan tantangan baru bagi strategi komunikasi pemasaran. Internet memberikan kesempatan pada pemasar dan konsumen untuk berinteraksi secara interaktif dan lebih mendalam. Dengan adanya pengguna internet sebanyak 3,8 miliar orang di dunia (www.liputan6.com, 2017), maka program komunikasi pemasaran yang komprehensif dewasa ini harus meliputi platform digital. Untuk beberapa kategori produk, seperti kosmetik, berbagai fenomena baru yang terjadi di media sosial memberikan peluang baru bagi pemasar dalam merancang strategi komunikasi pemasarannya.

Fenomena yang terjadi akhir-akhir ini di media Youtube adalah munculnya berbagai video tutorial make-up yang mengajarkan langkah demi langkah untuk mengaplikasikan berbagai alat make-up. Seseorang tampil dalam video untuk memperagakan dan mengajarkan keterampilan merias wajah dengan berbagai gaya, seperti gaya natural, gaya seperti artis K-POP, dan lain sebagainya. Berbagai video tersebut mendapatkan penonton yang cukup banyak. Sebagai contoh, unggahan video "Chic and Glowing Natural Make up Tutorial by Abel Cantika' di Youtube 
mendapatkan lebih dari 2 juta views. Platform yang disediakan oleh Youtube memungkinkan terjadinya komunikasi secara horizontal antara konsumen dengan konsumen, antara peer dengan peer, dan antarkelompok.

Platform ini tentu menarik pemasar untuk mengeksplorasi lebih lanjut, yaitu dari segi efektivitas media ini dilihat dari kemampuannya untuk menghasilkan minat beli bagi konsumen yang melihat video tutorial tersebut. Dalam perkembangannya, demonstrasi pemakaian make-up disertai dengan munculnya berbagai macam brand kosmetik yang sekaligus dipasarkan melalui video tutorial tersebut. Adanya perkembangan fenomena tersebut membuat pemasar perlu mengevaluasi secara sistematis dan objektif efektivitas dari video tutorial, yaitu berkenaan dengan konsumen yang suka/tidak suka terhadap video tutorial tersebut dan pengaruhnya dalam membangkitkan minat beli brand kosmetik yang digunakan. Selain itu, efektivitas penggunaan platform video tutorial sebagai media komunikasi pemasaran juga sangat tergantung pada karakteristik konsumen. Kelompok konsumen tertentu akan merespon stimulus pemasaran dengan cara yang berbeda dibandingkan kelompok konsumen lainnya (Kotler dan Keller, 2012). Dengan platform digital yang terbuka untuk diakses siapa saja, maka karateristik psikografis konsumen akan menjadi prediktor yang bisa bermanfaat untuk memahami respon konsumen terhadap video tutorial. Pengetahuan akan hal ini akan membantu pemahaman dan pengembangan lebih lanjut teori perilaku konsumen dalam dunia digital dan konsep pemasaran digital, serta menjadi dasar pengambilan keputusan bagi manajer pemasaran dalam merumuskan strategi komunikasi pemasaran.

Berdasarkan latar belakang tersebut, penelitian ini bertujuan untuk menguji pengaruh beberapa karakteristik psikografis konsumen yang relevan untuk memahami respon mereka terhadap pemasaran digital, yaitu purchase experience (pengalaman pembelian), consumer innovativeness (ke-inovatif-an konsumen), vanity seeking behavior (perilaku pencarian vaniti), dan variety seeking behavior (perilaku pencarian variasi) pada sikap terhadap video tutorial makeup dan selanjutnya pengaruh sikap terhadap video tutorial makeup pada pada brand image (citra merek) dan pengaruh citra merek pada purchase intention (minat beli). 


\section{REVIEW LITERATUR DAN HIPOTESIS}

\section{Pengaruh Karakteristik Psikografis Konsumen pada Sikap terhadap Video Tutorial Makeup}

Penelitian ini menggunakan empat segmen psikografis konsumen yaitu purchase experience (pengalaman pembelian), consumer innovativeness (ke-inovatifan konsumen), vanity seeking behavior (perilaku pencarian vaniti), dan variety seeking behavior (perilaku pencarian variasi).

Pengalaman pembelian diperoleh ketika seorang konsumen membeli produk. Pengalaman ini dapat berupa pengalaman yang menyenangkan ketika produk yang diperoleh sesuai dengan ekspektasi maupun pengalaman yang kurang menyenangkan ketika produk tidak sesuai dengan ekspektasi. Pengalaman ini dapat mempengaruhi sikap konsumen ketika melihat video tutorial makeup dari brand yang ia beli.

Sikap adalah evaluasi dalam waktu lama tentang yang disukai dan yang tidak disukai seseorang, perasaaan emosional dan kecenderungan tindakan terhadap beberapa objek atau ide (Kottler dan Keller, 2012: 186). Ini berarti bahwa sikap yang berkaitan dengan perilaku membeli terbentuk sebagai hasil dari pengalaman langsung mengenai produk, informasi secara lisan yang diperoleh dari orang lain atau terpapar oleh iklan di media masa, internet dan berbagai bentuk pemasaran langsung. Sikap dapat mendorong konsumen kearah perilaku tertentu atau menarik konsumen dari perilaku tertentu.

Oleh karena itu, pengalaman pembelian atau purchase experience dapat membentuk perilaku konsumen sehingga akan mempengaruhi sikap konsumen sebagai bentuk respon terhadap video tutorial makeup yang mereka lihat. Hipotesis yang dirumuskan adalah:

$\mathrm{H}_{1 \mathrm{a}}$ : Purchase experience berpengaruh positif pada sikap terhadap video tutorial makeup.

Innovativeness adalah suatu watak kepribadian yang sangat menekankan adopsi dari inovasi (Leavitt \& Walton 1975, 1988). Selanjutnya, Hurt et al. (1997) mendefinisikan innovativeness sebagai suatu keinginan untuk mengubah menjadi inovatif dan mencoba hal-hal baru (Goldsmith dan Flynn 2002, Roehrich 2004, Tellis et al. 2009). Goldsmith (2002) mengemukakan bahwa innovativeness adalah suatu 
kepribadian yang dibangun dan dimiliki dengan sendirinya pada suatu level yang lebih tinggi atau lebih rendah oleh semua individu karena setiap orang pada titik tertentu di hidup mereka akan mengadopsi ide-ide baru.

Seorang inovator didiskripsikan sebagai seorang individu yang terbuka pada pengalaman-pengalaman dan stimulasi baru serta memiliki kemampuan untuk memodifikasi informasi hal-hal baru seperti konsep, ide, produk atau jasa untuk pengunaan sendiri dan untuk mengenali aplikasi potensial dari ide-ide baru (Leavitt and Walton 1975, 1988). Pada konteks bisnis dan pemasaran, consumer innovativeness berkaitan dengan adopsi produk (Alcaniz et al. 2008). Hal ini karena kecepatan adopsi dapat dilihat setelah suatu produk memasuki pasar (Goldsmith dan Flynn, 1992).

Sikap merupakan reaksi yang diberikan terhadap video tutorial makeup yang dapat dipengaruhi oleh karakteristik konsumen yang salah satunya adalah consumer innovativeness sebagai salah satu segmen psikografis konsumen. Hipotesis yang diajukan adalah

$\mathrm{H}_{1 \mathrm{~b}}$ : Consumer innovativeness berpengaruh positif pada sikap terhadap video tutorial makeup.

Vanity seeking merupakan pemujaan atas penampilan. Konsumen dengan vanity seeking sangat concern terhadap penampilan. Orang yang memiliki concern tinggi terhadap penampilan sangat memperhatikan hal-hal yang mampu membuat penampilannya semakin baik. Salah satu hal yang mampu membuat penampilan semakin baik adalah makeup. Mulai dari makeup daily sampai untuk event-event tertentu. Mereka bisa melihat cara-cara makeup melalui video tutorial makeup yang sudah banyak beredar di internet.

Perilaku pencarian vaniti yang merupakan salah satu dari segmen psikografis juga merupakan suatu karakteristik konsumen. Karakteristik suatu konsumen mempengaruhi sikap mereka. Oleh karena itu, vanity seeking yang merupakan suatu karakteristik konsumen juga memiliki pengaruh pada sikap konsumen terhadap video tutorial makeup. Hipotesis yang diajukan adalah

$\mathrm{H}_{1 c}$ : Perilaku pencarian vaniti berpengaruh positif pada sikap terhadap video tutorial makeup. 
Konsumen pencari variasi terkadang melakukan brand switching atau peralihan merek sebagai ungkapan ketidakpuasan mereka terhadap produk atau suatu merek yang mereka evaluasi selama mengkonsumsi produk atau merek tersebut. Di sini sangat jarang konsumen setia atau loyal terhadap satu merek. Konsumen pencari variasi cenderung melakukan brand switching bukan saja karena tidak menyukai lagi merek yang telah ia pakai, namun terkadang ia hanya menginginkan varian yang berbeda.

Karakteristik konsumen dapat mempengaruhi sikap mereka terhadap sesuatu. Begitu juga varietyseeking yang memiliki pengaruh pada sikap konsumen terhadap video tutorial makeup. Hipotesis yang diajukan adalah:

$\mathrm{H}_{1 \mathrm{~d}}$ : Perilaku pencarian variasi berpengaruh positif pada sikap terhadap video tutorial makeup.

\section{Pengaruh Sikap terhadap Video Tutorial Makeup pada Brand Image}

Sikap merupakan interaksi manusia dengan objek tertentu. Sikap bukanlah suatu tindakan yang mempunyai hubungan yang saling terkait antara objek yang satu dengan objek yang lainnya. Jika interaksi yang diberikan konsumen terhadap komunikasi pemasaran ataupun produk di dalamnya menggambarkan tindakan yang diharapkan oleh pemasar maka hal itu dapat memberikan pengaruh positif pada brand image produk maupun perusahaan.

Sikap konsumen terhadap suatu hal akan memberikan stimulus pada pikirannya terhadap hal tersebut, salah satunya berupa image. Begitu pula sikap terhadap video tutorial makeup yang memiliki pengaruh pada brand image produk makeup tersebut. Hipotesis yang diajukan adalah

$\mathrm{H}_{2}$ : Sikap terhadap video tutorial makeup berpengaruh positif pada brand image.

\section{Pengaruh Brand Image pada Minat Beli}

Kotler dan Keller (2012: 270), mengatakan bahwa citra merek (brand image) adalah persepsi dan keyakinan yang dilakukan oleh konsumen, seperti tercermin dalam asosiasi yang terjadi dalam memori konsumen. Jadi, citra merek terbentuk melalui presepsi dan keyakinan konsumen terhadap suatu merek tertentu. Dari sebuah produk dapat lahir sebuah brand jika produk itu menurut persepsi konsumen mempunyai keunggulan fungsi (functional brand), menimbulkan asosiasi dan citra 
yang diinginkan konsumen (image brand) dan membangkitkan pengalaman tertentu saat konsumen berinteraksi dengannya (experiental brand).

Oleh karena itu, brand image suatu produk tentu memiliki pengaruh pada minat beli konsumen. Konsumen yang memiliki keyakinan akan suatu hal yang dapat dibeli tentu saja akan menimbulkan minat beli pada hal yang diyakininya. Setidaknya konsumen memiliki kemauan untuk mendekati hal tersebut.

$\mathrm{H}_{3}$ : Brand image berpengaruh positif pada minat beli.

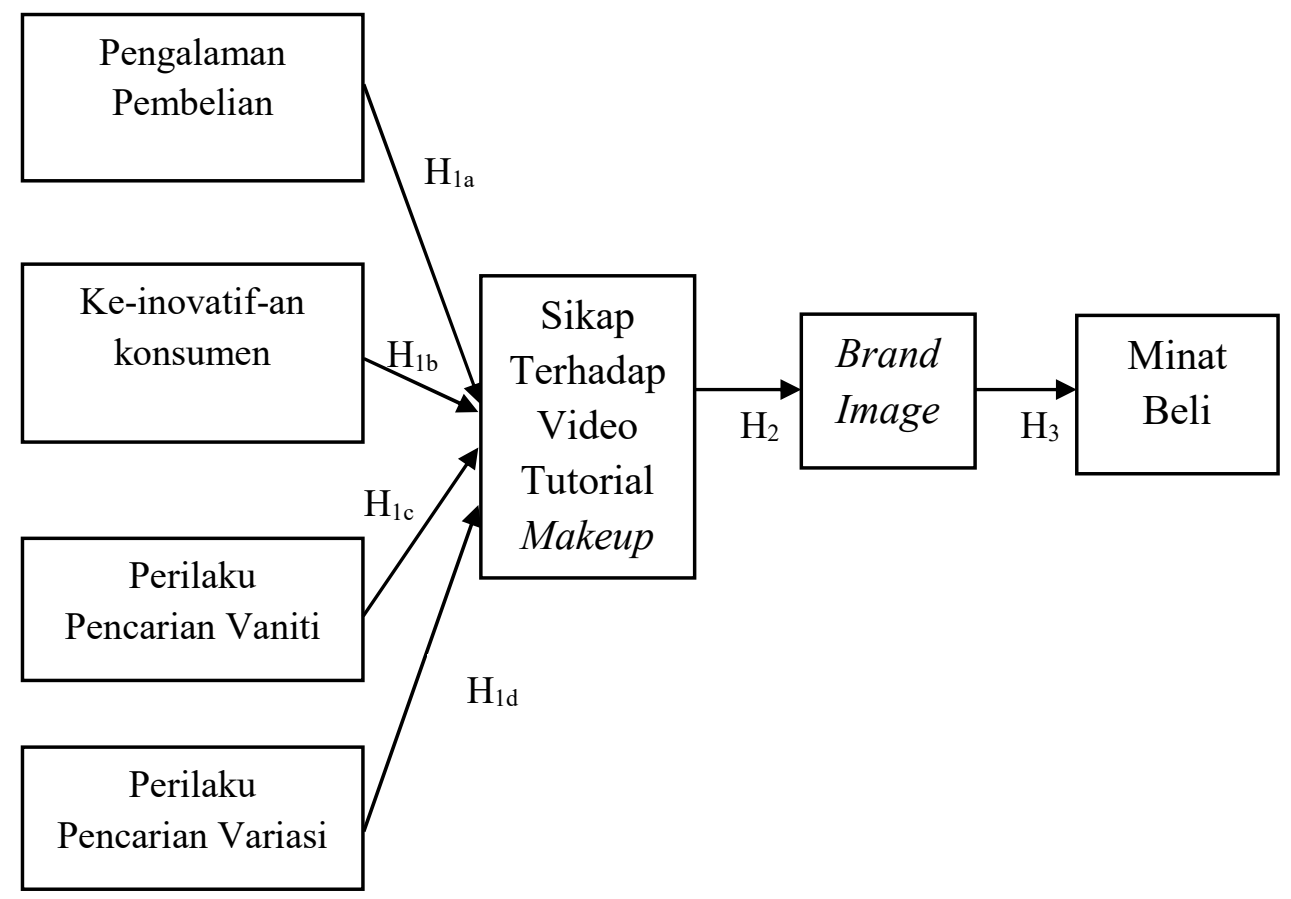

Gambar 1. Kerangka Pemikiran

\section{METODE PENELITIAN}

\section{Populasi dan Sampel}

Populasi dalam penelitian ini adalah semua perempuan yang bermukim di Yogyakarta, Sleman, dan Kebumen. Sampel dipilih menggunakan metode purposive sampling dengan kriteria perempuan yang berusia minimal 15 tahun, memiliki pendapatan/uang saku/ uang belanja minimal Rp500.000,- per bulan dan bersedia untuk menonton video tutorial makeup Em Cosmetics dan Lancôme. Penelitian ini menentukan 150 anggota sampel untuk setiap merek kosmetik sehingga jumlah total anggota sampel adalah 300. Kedua merek kosmetik tersebut dipilih karena keduanya 
tidak terlalu banyak dikenal di Indonesia, sehingga bisa meminimalkan pengaruh variabel lain di luar variabel yang diteliti.

\section{Variabel dan Pengukuran Variabel}

Pengalaman pembelian dioperasionalisasikan oleh 2 item yang diadaptasi dari Seock (2003) seperti dikutip oleh Nirmala dan Dewi (2011), yaitu: "Selama 12 bulan terakhir, telah banyak kosmetik yang saya beli" dan "Saya menilai bahwa saya berpengalaman dalam pembelian alat-alat kosmetik."

Ke-inovatif-an konsumen diukur menggunakan 4 item (Goldsmith, 2002 seperti dikutip oleh Nirmala dan Dewi, 2011), yaitu: "Pada dasarnya saya terbuka menerima ide-ide baru, "Saya merasa bahwa saya adalah orang yang inovatif", "Saya bersedia mencoba hal-hal baru," dan "Saya cenderung merasakan cara-cara baru dalam hidup dan melakukan perbaikan dari masa lalu."

Perilaku pencarian vaniti diukur dengan 7 item yang diadaptasi dari skala Netemeyer et al. (1995; seperti dikutip oleh Kamolwan dan Wiwatchai, 2010), yaitu: 1) Penting bagi saya untuk terlihat bagus (look good) sepanjang waktu, 2) Ketika saya berada di sekitar orang banyak, saya harus terlihat paling baik jika tidak saya akan merasa malu, 3) Saya bersedia berusaha keras untuk membuat diri saya terlihat paling bagus (look best), 4) Orang di sekitar saya bisa melihat daya tarik saya, 5) Saya ingin agar orang lain menghargai saya karena prestasi saya, 6) Jika dibandingkan dengan orang yang saya tahu/kenal, saya banyak menekankan dalam keberhasilan profesional lebih dari mereka, dan 7) Saya ingin orang lain memahami tentang prestasi saya.

Variabel berikutnya, yaitu Perilaku pencarian variasi diukur dengan 4 item yang dikembangkan dari Mehrabian dan Russell (1973; seperti dikutip oleh Schüssler, 2011) sebagai berikut: 1) Saya ingin mengalami hal-hal baru dan perubahan dalam hidup sehari-hari saya, 2) Saya terkadang mencari cara untuk mengubah rutinitas sehari-hari saya, 3) Saya ingin memiliki banyak kegiatan di sekitar saya, dan 4) Ketika makan di luar saya suka mencoba menu yang tidak biasa.

Sikap terhadap video tutorial makeup diukur dengan 5 item, yaitu: 1). Saya suka dengan video tutorial makeup tersebut, 2) Video tutorial makeup berguna bagi saya dalam memberi referensi produk dan tips-tips makeup, 3) Video tutorial makeup bermanfaat untuk menambah customer knowlegde saya, 4) Video tutorial makeup 
memberi pengalaman langsung bagi saya, dan 5) Video tutorial makeup meyakinkan saya akan produk tersebut.

Variabel brand image diukur dengan menggunakan 3 item pertanyaan yang diturunkan dari definisi brand image (Kotler dan Keller, 2012: 270), yaitu 1) Brand kosmetik yang digunakan dalam video tutorial makeup tersebut terkesan bagus dan berkualitas, 2) Brand kosmetik yang digunakan dalam video tutorial makeup tersebut memiliki manfaat yang luar biasa, dan 3) Brand kosmetik yang digunakan dalam video tutorial makeup tersebut memberikan hasil riasan yang sempurna.

Minat beli diukur dengan 4 item, yaitu: 1) Saya akan membeli brand kosmetik tersebut, 2) Saya akan membeli brand kosmetik tersebut untuk teman saya, 3) Saya akan merekomendasikan brand kosmetik tersebut kepada teman dan atau keluarga saya, 4) Saya akan mencari informasi mengenai brand kosmetik tersebut.

\section{Teknik Pengumpulan Data}

Alat pengumpulan data yang digunakan adalah kuesioner. Sebelum mengisi kuisioner responden diminta untuk menonton dan menyimak video tutorial makeup natural dari brand Em Cosmetic atau brand Lancome. Setelah itu, responden diminta untuk mengisi kuesioner yang terbagi menjadi dua bagian yakni bagian identitas diri dan bagian utama kuesioner. Pengukuran dilakukan dengan menggunakan Skala Likert (1-5) dengan alternatif respon " sangat tidak setuju”, "tidak setuju”, "netral", "setuju", dan "sangat setuju".

\section{Uji Validitas dan Reliabilitas}

Uji validitas instrumen penelitian dilakukan dengan analisis faktor konfirmatori. Hal ini dilakukan untuk menguji apakah butir-butir pertanyaan atau indikator yang digunakan dapat digunakan untuk mengkonfirmasi sebuah sebuah faktor atau konstruk atau variabel. Instrumen penelitian dikatakan valid jika nilai loading factor $>0,4$.

Uji reliabilitas digunakan untuk mengetahui seberapa jauh suatu instrumen dapat dipercaya. Uji ini dilakukan dengan menggunakan nilai Cronbach's Alpha. Jika nilai Cronbach's Alpha > 0,6 maka instrumen dikatakan reliabel (Gozali, 2007). 


\section{Uji Hipotesis}

1. Analisis Regresi Linier Berganda

Analisis ini digunakan untuk menguji pengaruh purchase experience (pengalaman pembelian), consumer innovativeness (ke-inovatif-an konsumen), vanity seeking behavior (perilaku pencarian vaniti), dan variety seeking behavior (perilaku pencarian variasi) pada sikap terhadap video tutorial makeup.

Persamaan regresi yang digunakan adalah

$\mathrm{Y}=\alpha+\mathrm{b}_{1} \mathrm{X}_{1}+\mathrm{b}_{2} \mathrm{X}_{2}+\mathrm{b}_{3} \mathrm{X}_{3}+\mathrm{b}_{4} \mathrm{X}_{4}+\mathrm{e}$

Keterangan :

$\mathrm{Y}=$ sikap terhadap video tutorial makeup

$\mathrm{X}_{1}=$ purchase experience (pengalaman pembelian)

$\mathrm{X}_{2}=$ consumer innovativeness (ke-inovatif-an konsumen)

$\mathrm{X}_{3}=$ vanity seeking behavior (perilaku pencarian vaniti)

$\mathrm{X}_{4}=$ variety seeking behavior (perilaku pencarian variasi)

2. Analisis Regresi Linier Sederhana

Analisis ini digunakan untuk menguji hipotesis kedua dan ketiga yaitu pengaruh sikap terhadap video tutorial makeup pada brand image dan pengaruh brand image pada minat beli.

\section{HASIL PENELITIAN DAN PEMBAHASAN}

\section{Deskripsi Responden}

Profil responden berpartisipasi dalam penelitian ini dapat dilihat pada tabel 1 berikut ini.

Tabel 1. Profil Responden

\begin{tabular}{|c|r|r|r|r|r|r|}
\hline Keterangan & \multicolumn{2}{|c|}{ Gabungan } & \multicolumn{2}{c|}{ Em Cosmetics } & \multicolumn{2}{|c|}{ Lancôme } \\
\hline Intensitas melihat video tutorial makeup & \multicolumn{1}{|c|}{$\mathbf{N}$} & \multicolumn{1}{c|}{$\%$} & \multicolumn{1}{c|}{$\mathbf{N}$} & \multicolumn{1}{c|}{ \% } & \multicolumn{1}{c|}{$\mathbf{N}$} & \multicolumn{1}{c|}{$\%$} \\
\cline { 2 - 7 } Pernah & 226 & 75 & 111 & $74 \%$ & 115 & $77 \%$ \\
Sering & 51 & 17 & 27 & $18 \%$ & 24 & $16 \%$ \\
Tidak Pernah & 23 & 8 & 12 & $8 \%$ & 11 & $7 \%$ \\
\hline Usia (tahun) & & & & & & \\
$15-19$ & 95 & 32 & 45 & $30 \%$ & 50 & $33 \%$ \\
$20-24$ & 179 & 60 & 86 & $57 \%$ & 93 & $62 \%$ \\
$25-29$ & 19 & 6 & 13 & $9 \%$ & 6 & $4 \%$ \\
$30-34$ & 5 & 2 & 5 & $3 \%$ & 0 & $0 \%$ \\
$35-39$ & 1 & 0 & 1 & $1 \%$ & 0 & $0 \%$ \\
$40-45$ & 1 & 0 & 0 & $0 \%$ & 1 & $1 \%$ \\
\hline
\end{tabular}


Tabel 1 (lanjutan). Profil Responden

\begin{tabular}{|c|c|c|c|c|c|c|}
\hline \multirow{3}{*}{$\begin{array}{c}\text { Keterangan } \\
\text { Tingkat pengeluaran per bulan (Rp) } \\
500.000-999.000\end{array}$} & \multicolumn{2}{|c|}{ Gabungan } & \multicolumn{2}{|c|}{ Em Cosmetics } & \multicolumn{2}{|c|}{ Lancôme } \\
\hline & $\mathbf{N}$ & $\%$ & $\mathbf{N}$ & $\%$ & $\mathbf{N}$ & $\%$ \\
\hline & 175 & 58 & 84 & $56 \%$ & 91 & $61 \%$ \\
\hline $1.000 .000-2.999 .000$ & 110 & 37 & 54 & $36 \%$ & 56 & $37 \%$ \\
\hline $3.000 .000-4.999 .000$ & 10 & 3 & 10 & 75 & 0 & $0 \%$ \\
\hline$\geq 5.000 .000$ & 5 & 2 & 2 & $1 \%$ & 3 & $2 \%$ \\
\hline Jenis pekerjaan & & & & & & \\
\hline Pelajar/ Mahasiswi & 268 & 89 & 125 & $83 \%$ & 143 & $95 \%$ \\
\hline Pegawai Swasta & 16 & 5 & 12 & $8 \%$ & 4 & $3 \%$ \\
\hline Wiraswasta & 9 & 3 & 7 & $5 \%$ & 2 & $1 \%$ \\
\hline Profesi & 5 & 2 & 4 & $3 \%$ & 1 & $1 \%$ \\
\hline PNS & 2 & 1 & 2 & $1 \%$ & 0 & $0 \%$ \\
\hline Pendidikan terakhir & & & & & & \\
\hline Tidak ada & 0 & 0 & 0 & $0 \%$ & 0 & $0 \%$ \\
\hline SD & 1 & 0 & 0 & $0 \%$ & 1 & $1 \%$ \\
\hline SMP/MTs & 4 & 1 & 1 & $1 \%$ & 3 & $2 \%$ \\
\hline SMA/SMK/MA & 227 & 76 & 112 & $75 \%$ & 115 & $77 \%$ \\
\hline D3-S1 & 62 & 21 & 33 & $22 \%$ & 29 & $19 \%$ \\
\hline $\mathrm{S} 2-\mathrm{S} 3$ & 6 & 2 & 4 & $3 \%$ & 2 & $1 \%$ \\
\hline
\end{tabular}

Tabel 1 menunjukkan bahwa mayoritas responden berusia 20-24 tahun, memiliki pengeluaran per bulan kurang dari satu juta rupiah dengan jenis pekerjaan pelajar/ mahasiswi serta memiliki pendidikan terakhir SMA/sederajat.

\section{Deskripsi Variabel Penelitian}

Analisis deskriptif variabel penelitian yang berupa nilai mean atau rata-rata dan standard deviation atau deviasi standar dari masing-masing variabel penelitian dapat dilihat pada tabel 2. Tabel tersebut menunjukkan bahwa nilai rata-rata terendah adalah purchase experience yakni 2,94 dan nilai rata-rata tertinggi adalah consumer innovativeness yakni 3,97. Namun jika dilihat dari masing-masing brand, nilai ratarata terendah Em Cosmetics adalah minat beli yakni 2,86. Sedangkan untuk Lancôme, nilai rata-rata terendah adalah purchase experience yakni 2,97. Nilai ratarata tertinggi baik Em Cosmetics maupun Lancôme sama-sama ditempati oleh consumer innovativeness. Jika dilihat dari masing-masing variabel, mulai dari purchase experience sampai dengan minat beli, Lancôme yang memiliki nilai ratarata lebih tinggi dari Em Cosmetics. Seperti pada variabel minat beli, Em Cosmetics memiliki nilai rata-rata 2,86 sedangkan Lancôme memiliki nilai rata-rata 3,04. Begitu pula variabel Sikap Terhadap Video Tutorial Makeup, Em Cosmetics dan Lancôme memiliki nilai rata-rata hampir sama, yaitu hanya selisih 0,02 . 
EXERO, Vol. 01, No. 01, November 2018 hal 23 - 43

Tabel 2. Statistik Deskriptif: Rata-rata dan Deviasi Standar

\begin{tabular}{|c|c|c|c|c|c|c|c|c|c|c|c|c|c|c|c|}
\hline \multirow{2}{*}{ No } & \multirow{2}{*}{ Variabel } & \multirow{2}{*}{ Operasionalisasi Variabel } & \multirow{2}{*}{ Kode } & \multicolumn{4}{|c|}{ Gabungan } & \multicolumn{4}{|c|}{ Em Cosmetic } & \multicolumn{4}{|c|}{ Lancôme } \\
\hline & & & & \multicolumn{2}{|c|}{ Rata-rata } & \multicolumn{2}{|c|}{ Dev.std } & \multicolumn{2}{|c|}{ Rata-rata } & \multicolumn{2}{|c|}{ Dev. std } & \multicolumn{2}{|c|}{ Rata-rata } & \multicolumn{2}{|c|}{ Dev.std } \\
\hline \multirow{2}{*}{1} & \multirow{2}{*}{$\begin{array}{l}\text { Purchase } \\
\text { Experience }\end{array}$} & $\begin{array}{l}\text { Selama } 12 \text { bulan terakhir, telah banyak } \\
\text { kosmetik yang saya beli }\end{array}$ & PE1 & 3,08 & \multirow{2}{*}{2,94} & 1,07 & \multirow{2}{*}{1,02} & 3 & \multirow{2}{*}{2,92} & 1,1 & \multirow{2}{*}{1,02} & 3,2 & \multirow{2}{*}{2,97} & 1,1 & \multirow{2}{*}{1,07} \\
\hline & & $\begin{array}{l}\text { Saya menilai bahwa saya berpengalaman } \\
\text { dalam pembelian alat-alat kosmetik }\end{array}$ & PE2 & 2,79 & & 0,98 & & 2,8 & & 1 & & 2,8 & & 1 & \\
\hline \multirow{3}{*}{2} & \multirow{3}{*}{$\begin{array}{l}\text { Consumer } \\
\text { Innovativeness }\end{array}$} & $\begin{array}{l}\text { Pada dasarnya saya terbuka menerima } \\
\text { ide-ide baru }\end{array}$ & CI1 & 4,04 & \multirow{3}{*}{3,97} & 0,63 & \multirow{3}{*}{0,68} & 3,9 & \multirow{3}{*}{3,9} & 0,7 & \multirow{3}{*}{0,72} & 4,1 & \multirow{3}{*}{4,03} & 0,5 & \multirow{3}{*}{0,67} \\
\hline & & Saya bersedia mencoba hal-hal baru & $\mathrm{CI} 2$ & 3,81 & & 0,74 & & 3,8 & & 0,8 & & 3,9 & & 0,7 & \\
\hline & & $\begin{array}{l}\text { Saya cenderung merasakan cara-cara baru } \\
\text { dalam hidup dan melakukan perbaikan } \\
\text { dari masa lalu }\end{array}$ & $\mathrm{CI} 3$ & 4,05 & & 0,69 & & 4 & & 0,7 & & 4,1 & & 0,7 & \\
\hline \multirow[t]{4}{*}{3} & \multirow{4}{*}{ Vanity Seeking } & $\begin{array}{l}\text { Penting bagi saya untuk terlihat bagus } \\
\text { (look good) sepanjang waktu }\end{array}$ & VAN1 & 4,02 & \multirow{3}{*}{3,63} & 0,74 & \multirow{3}{*}{$\mathbf{0 , 8 3}$} & 3,95 & \multirow{3}{*}{3,54} & 0,7 & & 4,1 & & 0,78 & \\
\hline & & $\begin{array}{l}\text { Ketika saya berada di sekitar orang } \\
\text { banyak, saya harus terlihat paling baik jika } \\
\text { tidak saya akan merasa malu }\end{array}$ & VAN2 & 3,34 & & 0,98 & & 3,17 & & 1 & 0,87 & 3,51 & 3,71 & 0,97 & 0,87 \\
\hline & & $\begin{array}{l}\text { Saya bersedia berusaha keras untuk } \\
\text { membuat diri saya terlihat paling bagus } \\
\text { (look best) }\end{array}$ & VAN3 & 3,66 & & 0,9 & & 3,64 & & 0,9 & & 3,67 & & 0,9 & \\
\hline & & $\begin{array}{l}\text { Orang di sekitar saya bisa melihat daya } \\
\text { tarik saya }\end{array}$ & VAN4 & 3,48 & & 0,72 & & 3,41 & & 0,7 & & 3,55 & & 0,71 & \\
\hline 4 & $\begin{array}{l}\text { Variety } \\
\text { Seeking }\end{array}$ & $\begin{array}{l}\text { Saya ingin mengalami hal-hal baru dan } \\
\text { perubahan dalam hidup sehari-hari saya }\end{array}$ & VAR1 & 4,08 & & 0,64 & & 4,05 & & 0,6 & & 4,11 & & 0,7 & \\
\hline & & $\begin{array}{l}\text { Saya terkadang mencari cara untuk } \\
\text { mengubah rutinitas sehari-hari saya }\end{array}$ & VAR2 & 3,93 & $20 ?$ & 0,73 & 070 & 3,95 & 70 & 0,7 & $0 ?$ & 3,91 & 00 & 0,76 & 001 \\
\hline & & $\begin{array}{l}\text { Saya ingin memiliki banyak kegiatan di } \\
\text { sekitar saya }\end{array}$ & VAR3 & 3,87 & 0,00 & 0,84 & 0,10 & 3,77 & קו, & 0,9 & 0,03 & 3,97 & 0,00 & 0,77 & 0.01 \\
\hline & & $\begin{array}{l}\text { Ketika makan di luar saya suka mencoba } \\
\text { menu yang tidak biasa }\end{array}$ & VAR4 & 3,45 & & 0,92 & & 3,38 & & 0,9 & & 3,52 & & 0,89 & \\
\hline
\end{tabular}


EXERO, Vol. 01, No. 01, November 2018 hal 23 - 43

Tabel 2 (lanjutan). Statistik Deskriptif: Rata-rata dan Deviasi Standar

\begin{tabular}{|c|c|c|c|c|c|c|c|c|c|c|c|c|c|c|c|}
\hline & \multirow{2}{*}{ Variabel } & \multirow{2}{*}{ Operasionalisasi Variabel } & \multirow{2}{*}{ Kode } & \multicolumn{4}{|c|}{ Gabungan } & \multicolumn{4}{|c|}{ Em Cosmetic } & \multicolumn{4}{|c|}{ Lancôme } \\
\hline & & & & \multicolumn{2}{|c|}{ Mean } & \multicolumn{2}{|c|}{ STDEV } & \multicolumn{2}{|c|}{ Mean } & \multicolumn{2}{|c|}{ STDEV } & \multicolumn{2}{|c|}{ Mean } & \multicolumn{2}{|c|}{ STDEV } \\
\hline \multirow{4}{*}{5} & \multirow{4}{*}{$\begin{array}{l}\text { Sikap } \\
\text { Terhadap } \\
\text { Video Tutorial } \\
\text { Makeup }\end{array}$} & $\begin{array}{l}\text { Saya suka dengan video tutorial makeup } \\
\text { tersebut }\end{array}$ & SKP1 & 3,81 & \multirow{4}{*}{3,84} & 0,84 & \multirow{4}{*}{0,79} & 3,8 & \multirow{4}{*}{3,84} & 0,9 & \multirow{4}{*}{0,78} & 3,81 & \multirow{4}{*}{3,86} & 0,81 & \multirow{4}{*}{0,79} \\
\hline & & $\begin{array}{l}\text { Video tutorial makeup berguna bagi saya } \\
\text { dalam memberi referensi produk dan tips- } \\
\text { tips makeup }\end{array}$ & SKP3 & 3,87 & & 0,77 & & 3,82 & & 0,8 & & 3,91 & & 0,77 & \\
\hline & & $\begin{array}{l}\text { Video tutorial makeup bermanfaat untuk } \\
\text { menambah customer knowlegde saya }\end{array}$ & SKP4 & 3,87 & & 0,76 & & 3,85 & & 0,7 & & 3,89 & & 0,78 & \\
\hline & & $\begin{array}{l}\text { Video tutorial makeup memberi } \\
\text { pengalaman langsung bagi saya }\end{array}$ & SKP5 & 3,82 & & 0,77 & & 3,87 & & 0,7 & & 3,77 & & 0,81 & \\
\hline & \multirow{3}{*}{ Brand Image } & $\begin{array}{l}\text { Brand kosmetik yang digunakan dalam } \\
\text { video tutorial makeup tersebut terkesan } \\
\text { bagus dan berkualitas }\end{array}$ & BI1 & 3,76 & \multirow{3}{*}{3,67} & 0,78 & \multirow{3}{*}{0,78} & 3,6 & \multirow{3}{*}{3,58} & 0,8 & \multirow{3}{*}{0,8} & 3,9 & \multirow{3}{*}{3,75} & 0,8 & \multirow{3}{*}{0,79} \\
\hline & & $\begin{array}{l}\text { Brand kosmetik yang digunakan dalam } \\
\text { video tutorial makeup tersebut memiliki } \\
\text { manfaat yang luar biasa }\end{array}$ & $\mathrm{BI} 2$ & 3,44 & & 0,75 & & 3,3 & & 0,7 & & 3,5 & & 0,8 & \\
\hline & & $\begin{array}{l}\text { Brand kosmetik yang digunakan dalam } \\
\text { video tutorial makeup tersebut } \\
\text { memberikan hasil riasan yang sempurna }\end{array}$ & BI3 & 3,8 & & 0,81 & & 3,8 & & 0,8 & & 3,8 & & 0,8 & \\
\hline \multirow{4}{*}{6} & \multirow{4}{*}{ Minat Beli } & $\begin{array}{l}\text { Saya akan membeli brand kosmetik } \\
\text { tersebut }\end{array}$ & MB1 & 2,8 & \multirow{4}{*}{2,95} & 0,78 & \multirow{4}{*}{0,85} & 2,7 & \multirow{4}{*}{2,86} & 0,8 & \multirow{4}{*}{0,9} & 2,9 & \multirow{4}{*}{3,04} & 0,8 & \multirow{4}{*}{0.89} \\
\hline & & $\begin{array}{l}\text { Saya akan membeli brand kosmetik } \\
\text { tersebut untuk teman saya }\end{array}$ & MB2 & 2,55 & & 0,8 & & 2,4 & & 0,7 & & 2,7 & & 0,8 & \\
\hline & & $\begin{array}{l}\text { Saya akan merekomendasikan brand } \\
\text { kosmetik tersebut kepada teman dan atau } \\
\text { keluarga saya }\end{array}$ & MB3 & 3,14 & & 0,83 & & 3 & & 0,8 & & 3,3 & & 0,8 & \\
\hline & & $\begin{array}{l}\text { Saya akan mencari informasi mengenai } \\
\text { brand kosmetik tersebut }\end{array}$ & MB4 & 3,31 & & 0,97 & & 3,3 & & 1 & & 3,3 & & 0,9 & \\
\hline
\end{tabular}




\section{Pengujian Validitas dan Reliabilitas Instrumen}

Hasil uji validitas instrumen dapat dilihat pada tabel 3 berikut ini:

Tabel 3. Hasil Uji Validitas

\begin{tabular}{|c|c|c|c|c|c|c|c|c|}
\hline \multirow{2}{*}{ Keterangan } & \multicolumn{7}{|c|}{ Komponen } & \multirow[t]{2}{*}{ Keterangan } \\
\hline & 1 & 2 & 3 & 4 & 5 & 6 & 7 & \\
\hline PE1 & & & & & & & 0,624 & Valid \\
\hline PE2 & & & & & & & 0,712 & Valid \\
\hline CI1 & & & & & 0,718 & & & Valid \\
\hline $\mathrm{CI} 2$ & & & & & 0,769 & & & Valid \\
\hline $\mathrm{CI} 3$ & & & & & 0,549 & & & Valid \\
\hline VAN1 & & & 0,637 & & & & & Valid \\
\hline VAN2 & & & 0,755 & & & & & Valid \\
\hline VAN3 & & & 0,799 & & & & & Valid \\
\hline VAN4 & & & 0,735 & & & & & Valid \\
\hline VAR1 & & & & & & 0,488 & & Valid \\
\hline VAR2 & & & & & & 0,775 & & Valid \\
\hline VAR3 & & & & & & 0,714 & & Valid \\
\hline VAR4 & & & & & & 0,519 & & Valid \\
\hline SKP1 & 0,562 & & & & & & & Valid \\
\hline SKP3 & 0,810 & & & & & & & Valid \\
\hline SKP4 & 0,797 & & & & & & & Valid \\
\hline SKP5 & 0,677 & & & & & & & Valid \\
\hline BI1 & & & & 0,775 & & & & Valid \\
\hline BI2 & & & & 0,777 & & & & Valid \\
\hline BI3 & & & & 0,763 & & & & Valid \\
\hline MB1 & & 0,789 & & & & & & Valid \\
\hline MB2 & & 0,744 & & & & & & Valid \\
\hline MB3 & & 0,761 & & & & & & Valid \\
\hline MB4 & & 0,683 & & & & & & Valid \\
\hline
\end{tabular}

Berdasarkan tabel 3, semua butir instrumen penelitian dikatakan valid karena semua item pertanyaan memiliki nilai loading factor di atas 0,4 . Hasil uji reliabilitas instrumen dapat dilihat pada tabel 4 berikut ini.

Tabel 4. Hasil Uji Reliabilitas

\begin{tabular}{|l|c|c|}
\hline \multicolumn{1}{|c|}{ Variabel } & Cronbach Alpha & Keterangan \\
\hline Purchase Experience & 0,749 & Reliabel \\
\hline Consumer Innovativeness & 0,590 & Reliabel \\
\hline Vanity Seeking & 0764 & Reliabel \\
\hline Variety Seeking & 0,614 & Reliabel \\
\hline $\begin{array}{l}\text { Sikap Terhadap Video Tutorial } \\
\text { Makeup }\end{array}$ & 0,552 & Cukup Reliabel \\
\hline Brand Image & 0,821 & Reliabel \\
\hline Minat beli & 0,848 & Reliabel \\
\hline
\end{tabular}

(Sumber: hasil olah data) 
Berdasarkan tabel 4, dapat dikatakan bahwa semua item pernyataan adalah reliabel karena nilai cronbach alpha di atas 0,6 . Sedangkan item pernyataan pada variabel Sikap Terhadap Video Tutorial Makeup cukup reliabel karena nilai cronbach alpha mendekati 0,6 .

\section{Uji Asumsi Klasik}

Uji asumsi klasik dalam penelitian ini meliputi uji normalitas, multikolinearitas, dan heteroskedastisitas. Hasil pengujian menunjukkan bahwa model regresi dari penelitian ini memenuhi uji asumsi klasik berupa residual terdistribusi normalitas, tidak terdapat multikolineritas, dan bebas dari heteroskedastisitas.

\section{Hasil Uji Hipotesis}

Pengujian hipotesis dilakukan dengan regresi linier berganda pada hipotesis pertama dan regresi linier sederhana pada hipotesis kedua dan ketiga. Semua hipotesis penelitian diterima kecuali hipotesis $1 \mathrm{~b}$ tentang consumer innovativeness. Hasil pengujian hipotesis dirangkum pada tabel 5 dan tabel 6 berikut ini :

Tabel 5. Rangkuman Hasil Uji Hipotesis Pengaruh Purchase Experience, Consumer Innovativeness, Vanity Seeking, Variety Seeking pada Sikap Terhadap Video Tutorial Makeup

\begin{tabular}{|c|c|c|c|c|c|c|}
\hline $\mathbf{H}$ & Rumusan Hipotesis & $t_{\text {hitung }}$ & $t_{\text {tabel }}$ & $b$ & Keterangan & Kesimpulan \\
\hline$H_{1 a}$ & $\begin{array}{l}\text { Purchase experience } \\
\text { berpengaruh positif pada sikap } \\
\text { terhadap video tutorial makeup. }\end{array}$ & 6,665 & 1,666 & 0,486 & $H_{1 a}$ diterima & $\begin{array}{l}\text { Purchase experience } \\
\text { berpengaruh positif pada } \\
\text { sikap terhadap video } \\
\text { tutorial makeup. }\end{array}$ \\
\hline$H_{1 b}$ & $\begin{array}{l}\text { Consumer innovativeness } \\
\text { berpengaruh positif pada sikap } \\
\text { terhadap video tutorial makeup. }\end{array}$ & 0,331 & 1,666 & 0,029 & $H_{16}$ ditolak & $\begin{array}{l}\text { Consumer innovativeness } \\
\text { tidak berpengaruh pada } \\
\text { sikap terhadap video } \\
\text { tutorial makeup. }\end{array}$ \\
\hline$H_{10}$ & $\begin{array}{l}\text { Vanity seeking berpengaruh } \\
\text { positif pada sikap terhadap } \\
\text { video tutorial makeup. }\end{array}$ & 2,964 & 1,666 & 0,15 & $\boldsymbol{H}_{1 \mathrm{c}}$ diterima & $\begin{array}{l}\text { Vanity seeking } \\
\text { berpengaruh positif pada } \\
\text { sikap terhadap video } \\
\text { tutorial makeup }\end{array}$ \\
\hline$H_{1 d}$ & $\begin{array}{l}\text { Variety seeking berpengaruh } \\
\text { positif pada sikap terhadap } \\
\text { video tutorial makeup. }\end{array}$ & 5,044 & 1,666 & 0,308 & $H_{1 d}$ diterima & $\begin{array}{l}\text { Variety seeking } \\
\text { berpengaruh positif pada } \\
\text { sikap terhadap video } \\
\text { tutorial makeup }\end{array}$ \\
\hline
\end{tabular}

(Sumber: hasil olah data) 


\section{Tabel 6. Rangkuman Hasil Uji Hipotesis PengaruhSikap Terhadap Video Tutorial Makeup pada Brand Image dan Pengaruh Brand Image pada Minat Beli}

\begin{tabular}{|c|c|c|c|c|c|c|}
\hline $\mathbf{H}$ & Rumusan Hipotesis & $\boldsymbol{t}_{\text {nitung }}$ & $\boldsymbol{t}_{\text {tabsl }}$ & $\boldsymbol{b}$ & Keterangan & \multicolumn{1}{|c|}{ Kesimpulan } \\
\hline $\boldsymbol{H}_{2}$ & $\begin{array}{l}\text { Sikap terhadap video tutorial makeup } \\
\text { berpengaruh positif pada brand image. }\end{array}$ & 9,746 & 1,66 & 0,711 & $\boldsymbol{H}_{2}$ diterima & $\begin{array}{l}\text { Sikap terhadap video } \\
\text { tutorial makeup } \\
\text { berpengaruh positif } \\
\text { pada brand image. }\end{array}$ \\
\hline$H_{3}$ & $\begin{array}{l}\text { Brand image berpengaruh positif pada } \\
\text { brand image. }\end{array}$ & 10,155 & 1,66 & 0691 & $H_{3}$ diterima & $\begin{array}{l}\text { Brand image } \\
\text { berpengaruh positif } \\
\text { pada minat beli. }\end{array}$ \\
\hline
\end{tabular}

(Sumber: hasil olah data)

\section{PEMBAHASAN}

Berdasarkan hasil analisis data purchase experience memiliki berpengaruh positif pada sikap terhadap video tutorial makeup. Hal ini berarti semakin banyak purchase experience yang dimiliki oleh seorang konsumen maka semakin suka juga sikapnya terhadap video tutorial makeup.

Namun, berbeda halnya dengan consumer innovativeness yang tidak berpengaruh pada sikap terhadap video tutorial makeup. Hal ini berarti keinovatifan konsumen tidak berpengaruh pada sikap terhadap video tutorial makeup. Hal ini dapat terjadi mengingat sifat dari consumer innovativeness yang selalu update akan hal-hal inovatif. Oleh karena itu, perusahaan harus lebih cepat dalam membuat media pemasarannya (video tutorial makeup) bahkan sebelum produk launching di pasar. Hal ini untuk menarik minat beli konsumen yang memiliki consumer innovativeness.

Vanity seeking berpengaruh positif pada sikap terhadap video tutorial makeup. Hal ini berarti sikap terhadap video tutorial makeup dapat dipengaruhi oleh karakteristik vanity seeking seorang konsumen. Semakin bagus vanity seeking seorang konsumen maka semakin suka juga sikapnya terhadap video tutorial makeup.

Variety seeking juga berpengaruh positif pada sikap terhadap video tutorial makeup. Variety seeking buying behavior adalah perilaku pembelian konsumen yang ditandai dengan keterlibatan rendah (Kotler dan Keller, 2012: 177). Variety seeking ini akan terus terjadi karena terdapat berbagai brand yang ditawarkan oleh produsen untuk produk-produk yang sejenis. Selain itu, manusia mempunyai sifat dasar selalu ingin mencari variasi dan mencoba sesuatu yang baru sesuai kebutuhan mereka. Oleh karena itu, sangat penting bagi perusahaan untuk memahami beberapa tipe konsumen 
dan selalu melakukan perbaikan terhadap produknya. Jadi, semakin beragam variety seeking seorang konsumen, semakin suka juga terhadap video tutorial makeup.

Sikap terhadap video tutorial makeup memiliki pengaruh positif pada brand image. Semakin suka sikap seorang konsumen terhadap video tutorial makeup maka semakin bagus pula brand image yang terbentuk dari produk kosmetik tersebut. Hal ini menandakan bahwa video tutorial makeup dapat membentuk brand image kosmetik tersebut. Brand image terbentuk melalui persepsi dan keyakinan konsumen terhadap suatu merek tertentu.

Minat beli adalah sesuatu yang timbul setelah menerima rangsangan dari produk yang dilihatnya, dari sana timbul ketertarikan untuk mencoba produk tersebut sampai pada akhirnya timbul keinginan untuk membeli agar dapat memilikinya (Kotler and Keller, 2012: 205). Hasil penelitian menunjukkan bahwa brand image berpengaruh positif pada minat beli. Artinya, semakin bagus brand image suatu produk yang diyakini seorang konsumen maka konsumen semakin ingin membeli, merekomendasikan, dan mencari informasi mengenai produk tersebut.

Jika dilihat dari nilai rata-rata pada setiap pernyataan kuesioner, hampir semua nilai rata-ratanya di atas 3 artinya sudah condong untuk setuju dengan pernyataan yang peneliti tuliskan di kuesioner. Sedangkan yang nilai rata-ratanya di bawah 3 hanya ada 3 pernyataan yakni PE2 dengan nilai 2,79 tentang penilaian pengalaman pembelian kosmetik, MB1 dengan nilai 2,8 tentang kesediaan untuk membeli produk kosmetik dalam video tutorial makeup yang telah ditonton, dan MB2 dengan nilai 2,55 tentang kesediaan untuk membeli produk kosmetik dalam video tutorial makeup yang telah ditonton untuk teman. Hal ini menandakan masih tipisnya minat transaksional responden (Ferdinand, 2002: 129).

Berbeda dengan variabel Sikap Terhadap Video Tutorial Makeup dan Brand Image yang memiliki nilai rata-rata 3,84 dan 3,67, variabel Minat Beli hanya memiliki nilai rata-rata 2,95. Akan tetapi, hasil penelitian memperlihatkan bahwa ternyata responden tetap tertarik dengan brand produk yang digunakan dalam video tutorial makeup yang telah ditontonnya dengan tetap mencari informasi brand produk tersebut dan merekomendasikan kepada orang lain. Hal ini dapat dilihat dari hasil nilai rata-rata pernyataan MB3 dan MB4, meskipun masih dalam rentang nilai 
rata-rata 3. Hal ini juga menandakan telah adanya minat referensial dan minat eksploratif dari responden terhadap brand produk tersebut (Ferdinand, 2002: 129).

Selain faktor di atas, untuk mendukung adanya minat beli bahkan pembelian aktual, maka perlu adanya dukungan dari faktor lain yang mempengaruhinya, antara lain pekerjaan, status sosial ekonomi, hobi, jenis kelamin, dan usia (Lidyawati, 2008). Jika dilihat dari hasil analisis deskriptif penelitian ini responden adalah pelajar/ mahasiswi (89\%) usia 20-24 tahun (60\%) yang berpendidikan SMA atau sedang berkuliah (76\%) dan dengan pengeluaran per bulan di bawah satu juta rupiah, maka hal ini juga dapat menjadi faktor masih rendahnya minat beli transaksional maupun pembelian aktual.

\section{KESIMPULAN DAN IMPLIKASI}

\section{Kesimpulan}

Berdasarkan hasil penelitian yang telah diuraikan dapat ditarik beberapa kesimpulan sebagai berikut:

1. Purchase experience berpengaruh positif pada sikap terhadap video tutorial makeup.

2. Consumer innovativeness tidak berpengaruh positif pada sikap terhadap video tutorial makeup.

3. Vanity seeking berpengaruh positif pada sikap terhadap video tutorial makeup.

4. Variety seeking berpengaruh positif pada sikap terhadap video tutorial makeup.

5. Sikap terhadap video tutorial makeup berpengaruh positif pada brand image.

6. Brand image berpengaruh positif pada minat beli.

\section{Implikasi Manajerial}

1. Perusahaan perlu mempertimbangkan untuk membuat media pemasaran melalui video tutorial makeup. Hal ini karena hasil penelitian menunjukkan bahwa video tutorial makeup memiliki pengaruh pada minat beli konsumen. Hal ini juga dilakukan untuk membentuk brand image perusahaan, karena video tutorial makeup ternyata juga mampu membentuk brand image.

2. Perusahaan tetap harus memperhatikan consumer innovativenesss dengan lebih cepat dalam membuat media pemasarannya (video tutorial makeup) bahkan sebelum produk launching di pasar. Hal ini untuk menarik minat beli konsumen 
yang memiliki consumer innovativeness. Misal dengan mencari informasi mengenai syarat atau faktor yang membuat suatu video tutorial makeup menarik sehingga konsumen tertarik untuk melihat dan membeli produk perusahaan.

3. Perusahaan perlu memperhatikan konten atau isi dari video tutorial makeup. Perusahaan harus jeli dalam melihat pasar dan karakteristiknya. Perusahaan dapat menggandeng para beauty blogger atau vlogger yang berkecimpung dalam dunia kecantikan untuk bekerja sama dalam pembuatan video tutorial makeup. Selain itu, kreativitas dalam membuat video tutorial makeup juga sangat penting. Perusahaan juga harus selalu memperbarui atau menambah jumlah video tutorial makeup-nya secara rutin (terjadwal) untuk menjaga konsistensi dan memudahkan konsumen untuk melihat video turorial make-up terbarunya. Perusahaan juga perlu untuk memasukkan karakteristik psikografis dalam penelitian ini ke dalam produk perusahaan, sehingga konsumen akan merasa bahwa jika konsumen menggunakan produk perusahaan maka hal itu dapat memperkuat jati dirinya (karakternya), tentunya dengan tidak melepaskan jati diri perusahaan (motto maupun positioning.

\section{Implikasi Penelitian Selanjutnya}

Penulis menyadari adanya keterbatasan dalam penelitian ini. Oleh karena itu, penulis menyarankan untuk penelitian selanjutnya sebagai berikut:

1. Menambah kriteria dari metode purposive sampling seperti karakteristik demografis dan keperilakuan konsumen.

2. Menambah atau menggunakan variabel lain di luar karakteristik psikografis konsumen.

3. Mengembangkan variabel minat beli menjadi minat beli ulang.

4. Menambahkan faktor pendukung bagus tidaknya suatu video tutorial makeup dalam penelitannya.

\section{DAFTAR REFERENSI}

Alcañiz, E.B., C.R. Mafe, J.A. Manzano, and S.S. Blas. 2008. Influence of online shopping information dependency and innovativeness on internet shopping adoption. Online Information Review 32 (5): 648- 667.

Ferdinand, Augusty. 2002. Metode Penelitian Manajemen. Semarang: Badan Penerbit Universitas Diponegoro. 
Ghozali, Imam. 2007. Aplikasi Analisis Multivariate dengan Program SPSS. Semarang: Badan Penerbit Universitas Diponegoro.

Goldsmith, R. E., and Flynn. 1992, "Identyfying innovators in consumer product markets," European Journal of Marketing Theory and Practice 10: 22-28.

Goldsmith, R. E. 2002. Explaining and predicting consumer intention to purchase over the internet: An exploratory study. Journal of Marketing Theory and Practice 10: 22-28.

Hurt, H. T., K. Joseph, and C. D. Cook. 1977. Scales for the measurement of innovativeness. Human Communication Research 5: 58-65.

Kamolwan, Tovikkai, and Wiwatchai Jirawattananukool. 2010. An Exploratory Study on Young Thai Women: Consumer Behavior toward Purchasing Luxury Fashion Brands. Mälardalen University Sweden.

Kotler, Philip and Kevin Lane Keller. 2012. Marketing Management. 14EEdition.NewJersey: Prentice Hall.

Leavitt, C., and J. R. Walton. 1975. Development of a scale for innovativeness. In Mary Jan Schlinger (Ed.), Advances in Consumer Research 2: 545-554. Provo: Association of Consumer Research.

Leavitt, C., and J. R. Walton. 1988. Opennes of information processing as a moderator of message effects on behavior. Working paper. College of Business Administration, Ohio State University.

Lidyawati. 2008. Hubungan antara Intensitas Menonton Iklan di Televisi dengan Perilaku Konsumtif. Skripsi (tidak diterbitkan). Surakarta: Fakultas Psikologi UMS.

Netemeyer, Ricard G., Burton Scot, and Donald R. Lichtenstein. 1995, "Trait Aspects of Vanity: Measurement and Relevance to Consumer Behaviors," Journal of Consumer Research. Vol. 21, No. 4, pp. 612-626.

Nirmala, Ratih Puspa dan Ike Janita Dewi. 2011, "The effect of Shopping Orientations, Consumer Innovativeness, Purchase Experience, and Gender on Intention to Shop for Fashion Products Online," Gadjah Mada International Journal of Business, Vol. 13, No. 1, pp. 65-83.

Schüssler, N. 2011. Psychometric Scales For Risk Propensity Environmentalism and Variety Seeking. Lausanne: EPF.

Seock, Y.K. 2003. Analysis of clothing website for young customer retention based on a model of customer relationship management via the internet. 
Unpublished dissertation. Faculty of theVirginia Polytechnic Institute and State University

Tellis, Gerard J., Yin, E., and Bel, Simon. (2009), "Global Consumer Innovativeness: Cross Country Differences and Demographic Commonalities," Journal of International Marketing, Vol. 17, No. 2, 2009, pp. 1-22.

https://www.liputan6.com/tekno/read/3051109/jumlah-pengguna-internetdunia-sentuh-38-miliar. 08 Agustus 2017, 17:00 WIB. Diakses tanggal 16 September2018. 